a new way of presenting Arctic history, but rather to generate a comprehensive volume on the matter to non-professionals in the field. The difference to other 'histories' on the Arctic is that McCannon's book does not just focus on one particular aspect of Arctic history, but that it is an encompassing swing at the history of the north. And this comes particularly to the fore in his gripping chapter Subjugations: 1914 to 1945. While not delving into too much detail, as nowhere in the book really, this chapter results in a few pages on the Second World War that vividly describe the war-driven transformation of the Arctic: while before the war it was still considered a frontier and almost a boundary that claimed many a life due to its remoteness, during the war it became a theatre of military conflict and the 'Arctic regions were now physically accessible. They were economically valuable' (page 235).

This trend continues in the times after the war that McCannon eloquently describes and summarises in Contaminations: 1945 to 1991. Here he covers the anthropogenic environmental changes, the military build-up and of course the changes in Arctic demographics. And it is impressive how the author manages to filter and present the most important elements of the complex geopolitical and socio-economic developments that had taken a hold of the Arctic during that time. Given the scope of the book, McCannon does not delve deeply into specific events or does not get lost in historical interpretations. Instead, he establishes linkages, such as the influence of the emerging environmental movement in the 1960s on changes in native livelihoods that he briefly describes and contextualises.

And here lies probably the keyword of $A$ history of the Arctic: contextualisation. The book reads from top to back like one comprehensive narrative. The author has created a timeline of events that feed into each other, influence one another and build on top of each other until we have reached the Extinctions: 1991 to the present. The 'present' obviously ends in 2012. It is thus that the book does not cover most recent developments in Ukraine and its (possible) effects on Arctic cooperation. Also, for example, McCannon's assertion that the Goliat gas field in the Barents see would start production in 2013 (page 288) has thus far not occurred. Be that as it may, also in this last chapter the author manages impressively to summarise key events and key developments in combination with the ongoing discourse on the Arctic, its environment, climatic changes and peoples. But he does not end on a too positive note as the two last sentences of this volume show: 'I myself confess to dark expectations about whether we will set our course correctly and respond adequately or in time. I hope for nothing more than to be proven wrong' (page 307).

With this A history of the Arctic ends and leaves this reviewer deeply impressed by the eloquence with which McCannon has approached the theme of the book. While sources are provided these are not too numerous and the reader is compelled to be delving into a narrative of the Arctic that reads more like a novel than a fact-based book. It is in that sense a popular scientific volume. Note also that with the titles of each chapter, the author provides a keyword that frames the main focus of the respective chapter and filter the most important retrospective discourse on the Arctic for that particular time. And while the book does not contain much 'new' historical information, it is nevertheless so nicely compiled and arranged that it should be a prerequisite for all those interested in Arctic history and / or engage in studying the Arctic one way or the other. (Nikolas Sellheim, Faculty of Law, University of Lapland, PO Box 122, 96101 Rovaniemi, Finland. (nikolas.sellheim@ulapland.fi)).

\section{THE LAST OF THE ICE HUNTERS. AN ORAL HISTORY OF THE NEWFOUNDLAND SEAL HUNT. Shannon Ryan. 2014. St. John's: Flanker Press Ltd. xvi + 460 p, softcover. ISBN 978-1-77117-316-2. CA $\$ 21.95$. \\ doi:10.1017/S0032247415000571}

It has not been long that this reviewer was to review John Gillett's memoirs as a sealer in the Newfoundland seal hunt (Gillett 2015). From the same publisher now comes an additional volume dealing with the controversial commercial seal hunt still carried out in Atlantic Canada. However, while Gillett's account stretches into the present, Shannon Ryan presents an oral history of the seal hunt up until 1950. This date has not been chosen incidentally, but it marks the end of the Newfoundland seal hunt to become the Canadian seal hunt, given that Newfoundland became part of Canada in 1949 (page 42).

The present volume is subdivided into two major parts, plus an introduction and a short conclusion by the author. It consists primarily of interviews that were carried out in the 1970s and 1980s with sealers, business workers associated with the sealing industry and others one way or the other engaged in the seal hunt. The outcome is a deeply moving insight into the conditions of the large-scale, indeed highly commercial seal hunt which can no longer be compared to the still ongoing, much smaller scale hunt.
But this volume is much more than a reproduction of interviews. It is a window into the past of Newfoundland as a whole as the interviewees present a plethora of different facets of the living conditions on an island which has been subject to the harsh north Atlantic climate. This is particularly the case in the first of the two major parts, entitled Long interviews: setting the stage. Here, as the title implies, interviews, or to be more precise, monologues, of the interviewees stretch over several pages and open up the sealing industry as a historical and crucially important industry for the economy and identity of the island and for the islanders. For example, the accounts of the sealers themselves who engaged in the hunt on the large steamers that found their introduction into the hunt in the early 20th century offers an insightful account of the human dimension of this activity, often labeled as 'barbaric.' From an ethnographic perspective these accounts are invaluable as they make the motivations behind the hunt, the interaction between the sealers and the dangers which they were exposed to more understandable.

The ethnographic importance of this work is emphasised by the second large part of this book, Interview extracts with selected topics. While indeed the first 120 pages set the stage, the second part of the book serves as a work of reference and the reader is able to understand the cultural dimension of the seal hunt for Newfoundland. Here, especially the keywords such as 'accident', 'danger', 'death', 'Newfoundland disaster', the darkest year in Newfoundland sealing history when 273 
sealers lost their lives in 1914, or 'storm' stand out. Many interview partners refer to these, signifying the harsh conditions under which the seal hunt was, and still is, conducted. But also other keywords, such as 'berth', a prerequisite and much aspired part for a sealer to participate in the seal hunt, or 'food' make Ryan's interview compilation an important tool to further engage in ethnographic studies of the seal hunt. This is in particular relevant for a comparative angle on the issue, especially when it comes, for example, to conflict and resolution thereof or competition. Interestingly, Ryan's interview partners show that this was a serious issue in the large-scale seal hunts of the early 20th century. However, 100 years later, it is rather the notion of sharing than competition which shapes the interaction between sealers (Sellheim in press). This points to significant differences in the characteristics of the hunt: while Ryan unveils the inherent business-nature of the sealing industry, contemporary hunts are rather to be located within a 'makinga-living' narrative as procured by Gillett (2015) and others in Newfoundland.

The first 40 or so pages of The last of the ice hunters are a brief summary of Ryan's treatise The ice hunters (Ryan 1994). Here, the reader is provided with core information on the history of the Newfoundland seal hunt that enable him/her to understand the presented interviews and data in a much better way. Indeed, without such introduction and without prior knowledge about the history of the hunt and the industry the reader would be lost. However, it seems as if Ryan or the publisher do expect the reader to have at least some knowledge on the hunt and Newfoundland culture anyway. For example, reference is made to the 'Front' (for example on page 40) on several occasions in the book, however without explanation. The 'Front' refers to the waters northeast of Newfoundland as an historical distinction to the 'back', the Gulf of St Lawrence. Or, Ryan refers to 'brewis' (page 34), a specific type of hard bread, that the reader may not be familiar with. While certainly nothing major, the structure and content of the book in combination with these minor editorial issues do not make The last of the ice hunters a stand-alone work. Yet, this does not seem to be the intention in the first place. After all, in the Conclusion Ryan notes that he has tried to do "justice to their [the sealers] careers and lives in the sealing industry [...] by publishing The ice hunters (1994) and now by inviting them to speak for themselves' (page 427). In other words, the present volume is best understood when read in conjunction with Ryan's earlier work.

However, the historical value of this work cannot be underestimated. While more of general interest to the readers of Polar Record, The last of the ice hunters sheds light on the sociocultural value of the seal hunt for the island of Newfoundland. It is therefore an important contribution to the ethnographic study of this controversial hunt whose political dimension has direct effects on (sub-)Arctic livelihoods. But in order to gain more general information on the hunt, especially in its contemporary form, this reviewer would suggest to turn elsewhere. But for historians, anthropologists and other social scientists this book is certainly truly interesting (Nikolas Sellheim, Faculty of Law, University of Lapland, PO Box 122, 96101 Rovaniemi, Finland (nikolas.sellheim@ulapland.fi)).

\section{References}

Gillett, J. 2015. Leaving for the seal hunt. The life of a swiler. St. John's: Flanker Press Ltd.

Ryan, S. 1994. The ice hunters. A history of Newfoundland sealing to 1914. St. John's: Breakwater Books Ltd.

Sellheim, N. In press. Morality, practice and economy in a commercial sealing community. Arctic Anthropology 52 (1): 61-80.
THE TRAVELS OF THE OOSTENDE WHALE SKELETON. Nicholas Redman. 2015. Redman Publishing. 119p, illustrated, hardcover. ISBN 978-83-64313-745. $£ 17.50$.

doi:10.1017/S0032247415000583

The blue whale, a living mammal and the largest of all living creatures, is accustomed to cover many thousands of miles across the world's oceans. The skeleton of an example of this species which now resides in the Russian Academy of Science in St. Petersburg has certainly travelled more miles by land, sea and waterway than any other cetacean remains.

From the moment it cast ashore in Ostend harbour in November 1827 , the creature became a celebrity and attracted great crowds. The fishermen who had towed it from the North Sea were allowed to display it for a few days to raise money, after which the stench must have been hard to bear. After that, the carcase was bought by a local philanthropist Herman Kessels and a Dr. Dubar who superintended the dissecting out of the skeleton while the public gathered again to watch this procedure. The latter published a book with detailed drawings of the bones. A contemporary print shows this work at an advanced stage and depicts couples dancing a quadrille within the space made by the lower jaws laid on the ground, the skull being raised by a set of sheer legs. It became part of the festival to celebrate the birthday of Queen Wilhelmina on 18 November, and the whale was nominally presented to King Willem I of the United Kingdom of the Netherlands.

It was the intention to take the skeleton on tour and charge visitors for the privilege of seeing this monster of the deep which was a full 95 feet in length. A prefabricated wooden pavilion, pierced by windows to admit daylight, was built and used for the first time on the quayside in Ostend in April 1828 before proceeding to Ghent, Brussels, and Amsterdam, then Den Haag, Rotterdam, Dordrecht and Antwerp in its first year of peregrination. At Ghent a concert was held with the orchestra seated inside the rib cage, a performance which became a regular feature of its display. At other times the suspended platform was used as a lounge where visitors could sit at tables and browse through scientific books and albums of ephemera relating to the whale and its movements across Europe.

After exhibition in the Place de la Concorde in Paris, the skeleton was taken by sea to Bordeaux before arriving in England where the pavilion was set up in the Kings Mews, Charing Cross, in July 1831. Here the advertising literature incorrectly refers to it as a Greenland whale. Probably this was because the Right Whale was the type most familiar in Britain, thanks to the extensive Arctic whaling trade, but this was another kind of baleen whale, of the type described as rorquals.

Returning to Ostend, the skeleton was taken through Germany and Austria and further on to Prague where it is said to have been seen by more than 80,000 individuals, some 